\title{
Outer-membrane protein and lipopolysaccharide variation in Pasteurella haemolytica serotype A1 under different growth conditions
}

\author{
R. L. Davies, ${ }^{1 *}$ R. Parton, ${ }^{1}$ J. G. Coote,${ }^{1}$ H. Alison Gibbs ${ }^{2}$ and J. H. Freer ${ }^{1}$ \\ Departments of Microbiology ${ }^{1}$ and Veterinary Medicine, ${ }^{2}$ University of Glasgow, Glasgow, G12 8QQ, UK
}

(Received 25 November 1991; accepted 8 January 1992)

\begin{abstract}
Growth characteristics, as well as outer-membrane protein (OMP) and lipopolysaccharide (LPS) profiles in SDS-polyacrylamide gels, of two serotype A1 isolates of Pasteurella haemolytica were examined under different in vitro growth conditions. The two isolates were chosen as representatives of disease (S/C 82/1) and non-disease (W/D 83/4) isolates, respectively. The growth rates and final cell densities of both isolates increased as the degree of aeration increased. In particular, the final cell densities varied significantly according to the degree of aeration. Under anaerobic conditions, however, both the growth rate and final cell density were significantly reduced. There was reduced expression of a $40.5 \mathrm{kDa}$ protein under anaerobic conditions in both isolates, whereas in S/C 82/1 expression of the 71, 77 and $100 \mathrm{kDa}$ iron-regulated proteins increased as aeration decreased. There were also differences in low-molecular-mass components of LPS between cells grown anaerobically and those grown aerobically. Growth in the presence of $5 \% \mathrm{CO}_{2}$ did not significantly alter the growth rate and had little, if any, affect on OMPs or LPS. Differences in the expression of certain proteins occurred as growth progressed from the exponential to the stationary phase. Growth in the presence of the iron chelators $2,2^{\prime}$-dipyridyl, ethylenediaminedihydroxyphenylacetic acid (EDDA), desferrioxamine mesylate (desferal), ovotransferrin (conalbumin) and bovine transferrin was inhibited within a very narrow concentration range. In the presence of $2, \mathbf{2}^{\prime}$-dipyridyl, EDDA or desferal, 71 and $100 \mathrm{kDa}$ iron-regulated OMPs increased in both isolates whereas a $77 \mathrm{kDa}$ protein increased in isolate $\mathrm{S} / \mathrm{C} \mathrm{82/1}$ only. In the presence of ovotransferrin or bovine transferrin there was, in both isolates, increased expression of the $71 \mathrm{kDa}$ protein, a slight increase in expression of the $100 \mathrm{kDa}$ protein but no expression of the $77 \mathrm{kDa}$ protein; there was also increased production of the $40.5 \mathrm{kDa}$ protein, and synthesis of two additional proteins of 23 and $26 \mathrm{kDa}$. Other differences occurred after growth in foetal and newborn calf sera. In foetal calf serum there was enhanced expression of the 71 but not of the $100 \mathrm{kDa}$ protein. In newborn calf serum there was no enhanced expression of the 71, 77 or $100 \mathrm{kDa}$ proteins, but expression of novel proteins of 97 and $98 \mathrm{kDa}$ as well as a high-molecular-mass protein occurred. There were also slight quantitative differences in the LPS profiles of cells grown in foetal or newborn calf sera compared to those of cells grown in other media. Addition of $\mathrm{FeCl}_{3}$ to the various media caused repression of synthesis of the 71, 77 and $100 \mathrm{kDa}$ proteins in the presence of EDDA and repression of the $71 \mathrm{kDa}$ protein in the presence of ovotransferrin and in foetal calf serum, but caused no change to the expression of proteins in newborn calf serum. Thus, marked changes may occur in the OMP and LPS components of the outer membrane of $P$. haemolytica when growth conditions are altered; some of these changes may occur in vivo.
\end{abstract}

\section{Introduction}

Pasteurella haemolytica is a Gram-negative bacterium responsible for diseases of ruminants including bovine pneumonic pasteurellosis or shipping fever (Carter,

- Author for correspondence. Tel. (041) 3398855 ext. 5840; fax (041) 3304600 .

Abbreviations: OMP, outer-membrane protein; LPS, lipopolysaccharide; EDDA, ethylenediaminedihydroxyphenylacetic acid.
1967). Although two biotypes, $A$ and $T$, and 16 serotypes have been identified (Biberstein, 1978; Fodor et al., 1988) the majority of disease outbreaks in cattle are due to biotype A, serotype 1 (A1) strains (Frank, 1979). Experimental vaccines against bovine pneumonic pasteurellosis, including both live and killed bacteria (Wilkie et al., 1980; Confer et al., 1985; Purdy et al., 1986) as well as various extracts (Gilmour et al., 1982; Yates et al., 1983), have generally been unsuccessful. Although leukotoxin-neutralizing antibodies appear to 


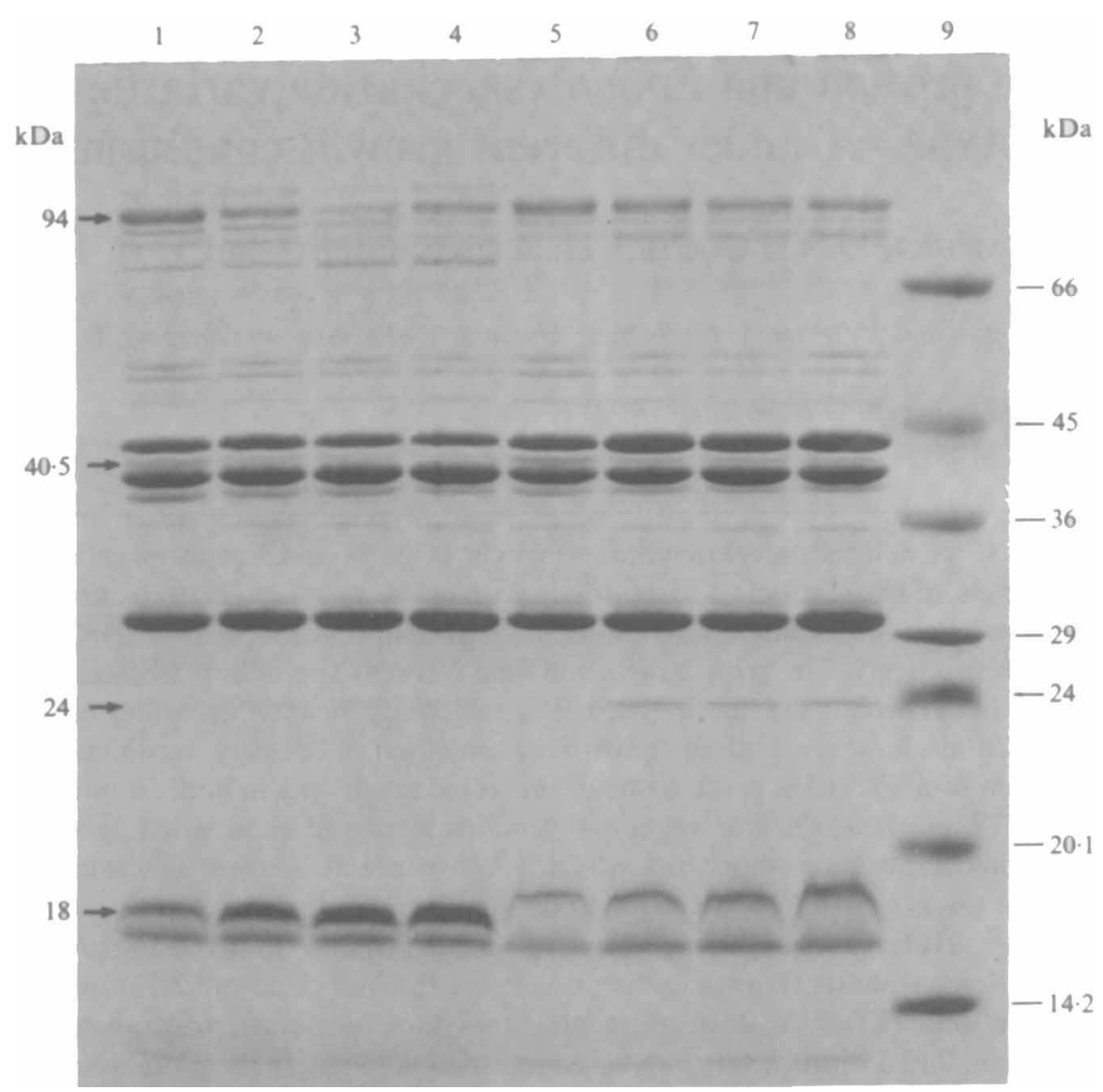

Fig. 1. OMP profiles of isolate S/C 82/1 (lanes 1-4) and W/D 83/4 (lanes 5-8) after 3.5 (lanes 1 and 5), 6.5 (lanes 2 and 6), 12 (lanes 3 and 7) and 24 (lanes 4 and 8 ) h of growth in BHIB with high aeration. Molecular mass markers (lane 9) are bovine serum albumin (66 kDa), ovalbumin $(45 \mathrm{kDa})$, glyceraldehyde-3-phosphate dehydrogenase $(36 \mathrm{kDa})$, carbonic anhydrase $(29 \mathrm{kDa})$, trypsinogen $(24 \mathrm{kDa})$, trypsin inhibitor (20.1 kDa) and $\alpha$-lactalbumin (14.2 kDa) (Sigma). Numbers on the left indicate molecular masses of proteins which exhibited variation in expression during the growth cycle (see text).

be important in protection against pneumonic pasteurellosis (Shewen \& Wilkie, 1983) other somatic antigens are also involved in inducing resistance (Shewen \& Wilkie, 1988). As a result, recent research has attempted to identify important immunogenic components of $P$. haemolytica such as cell wall and capsular materials (Durham et al., 1986), carbohydrate-protein subunits (Lesley et al., 1985), lipopolysaccharide (LPS) (Confer $e t$ al., 1986) and various outer-membrane proteins (OMPs) (Squire et al., 1984; Nelson \& Frank, 1989; Knights et al., 1990; Craven et al., 1991) including iron-regulated OMPs (Donachie \& Gilmour, 1988; Deneer \& Potter, 1989; Gilmour et al., 1991).

It is now well-recognized that the expression of antigens in bacteria obtained directly from the infected host may be quite different to those expressed in vitro (Smith, 1990). In particular, a number of OMPs are induced in various bacteria growing in vivo which are not expressed in standard laboratory media, but are expressed in vitro under iron-limited conditions (Griffiths $e t$ al., 1983; Brown et al., 1984). Such iron-regulated OMPs are immunogenic (Anwar et al., 1984; Black et al., 1986; Ward et al., 1988), may induce bactericidal antibodies (Pettersson et al., 1990), can be protective (Bolin \& Jensen, 1987) and hence are likely vaccine candidates (Banerjee-Bhatnagar \& Frasch, 1990). Although the in vivo expression of cell-surface antigens of a serotype A2 strain of $P$. haemolytica has been studied in sheep (Donachie \& Gilmour, 1988; Sutherland et al., 1990), little is known about the expression of such antigens in serotype Al strains isolated from cattle. Cells of a sheeppathogenic A2 strain of $P$. haemolytica recovered directly without subculture from the pleural fluid of an infected lamb expressed two additional envelope proteins of 70 and $100 \mathrm{kDa}$; these proteins were also induced in vitro under iron-restricted conditions (Donachie \& Gilmour, 

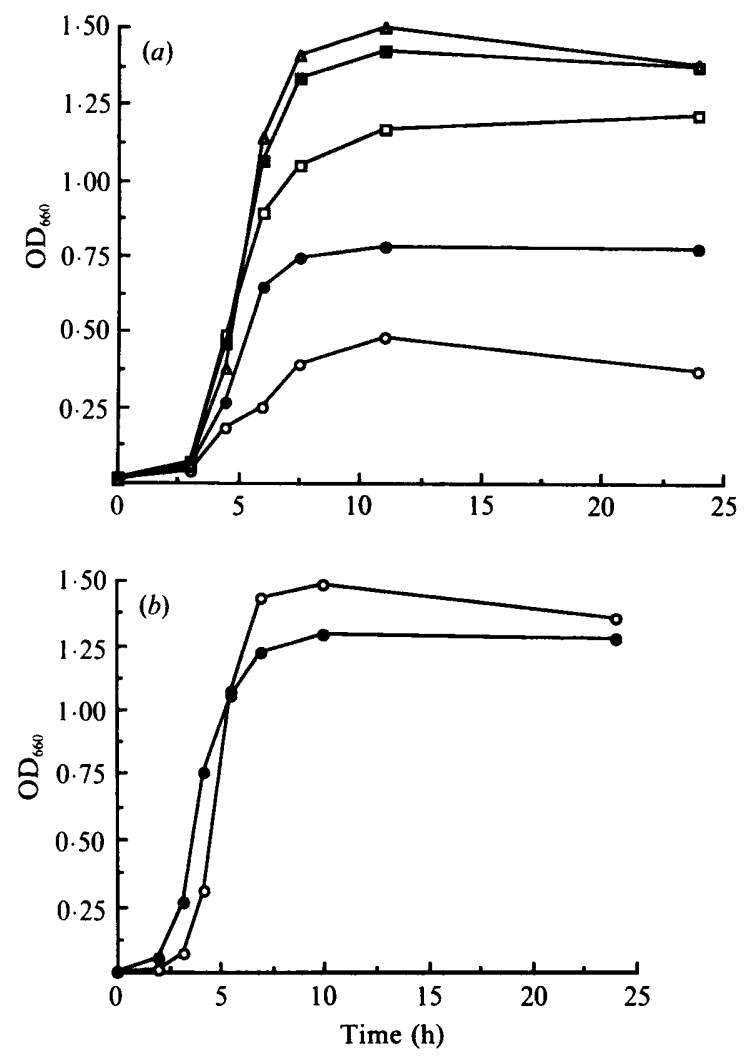

Fig. 2. Growth of isolate W/D 83/4 under various conditions of aeration. (a) compares growth with no aeration $(0)$, low aeration $(\bullet)$, moderate aeration $(\square)$, high aeration $(\square)$ and very high aeration $(\Delta) .(b)$ compares growth in $5 \% \mathrm{CO}_{2} / 95 \%$ air $(\bullet)$ with growth in air alone $(O)$.

1988). Sutherland et al. (1990) similarly identified 70 and $100 \mathrm{kDa}$ proteins in A2 cells grown in chambers implanted into the peritoneal cavity of sheep. Three ironregulated OMPs of 71,77 and $100 \mathrm{kDa}$ were demonstrated in in-vitro-grown strains of $P$. haemolytica belonging to 12 serotypes in response to iron-limitation by Deneer \& Potter (1989) and these authors provided evidence to suggest that these proteins were expressed in vivo in cattle.

In addition to iron-limitation other factors which may cause changes to OMPs of Gram-negative bacteria include phase of growth (Loeb \& Smith, 1980; Kelly \& Parker, 1981; Blaser et al., 1983; Davies, 1991) and the degree of aeration or $\mathrm{CO}_{2}$ tension during growth (Clark et al., 1987; Denyer et al., 1990; Lee \& Falkow, 1990; Schiemann \& Shope, 1991). Although there is much less information on differences in LPS structure between in-vivo- and in-vitro-grown cells, differences have been described in Pseudomonas aeruginosa (Kelly et al., 1989) and Neisseria gonorrhoeae (Mandrell et al., 1990). Changes in the LPS of Neisseria meningitidis due to differences in aeration and medium composition have also been described (Tsai et al., 1983). However, the LPS of an in-vitro-grown $P$. haemolytica A2 strain did not appear to differ from that of the same strain grown in a peritoneal chamber implant in sheep (Sutherland et al., 1990).

In the present study, the objectives were to examine the growth characteristics and the variation in OMP and LPS profiles of $\boldsymbol{P}$. haemolytica $\mathrm{Al}$ isolates under various conditions of in vitro growth. Two isolates were chosen for comparison, one isolate from a confirmed case of pasteurellosis and the other from a healthy animal. Previous studies on $P$. haemolytica have utilized the chelating agents $2,2^{\prime}$-dipyridyl, ethylenediaminedihydroxyphenylacetic acid (EDDA) or desferrioxamine mesylate (desferal) to induce iron-limited growth conditions in conventional media (Donachie \& Gilmour, 1988; Deneer \& Potter, 1989; Ogunnariwo \& Schryvers, 1990, Lainson et al., 1991). However, Chart et al. (1986) demonstrated that various chelating agents have differing effects on the induction of the iron-regulated OMPs of Escherichia coli. Thus, in addition to 2,2'-dipyridyl, EDDA and desferal, the effects of the chelators ovotransferrin (conalbumin) and bovine transferrin were also compared in the present study. As well as examining the effects of various chelating agents, bacteria were also grown in foetal and newborn calf sera. In addition, OMP and LPS profiles were examined at different stages of the growth cycle and under different conditions of aeration and $\mathrm{CO}_{2}$ tension, both of which are additional factors which could influence in vivo profiles.

\section{Methods}

Bacterial strains and growth conditions. Two biotype A, serotype 1 (A1) strains (S/C 82/1 and W/D 83/4) of P. haemolytica were used in the study. Strain S/C $82 / 1$ was isolated from a confirmed case of bovine pneumonic pasteurellosis whereas strain W/D 83/4 was isolated from the nasopharynx of a clinically healthy calf on a disease-free farm. The LPSs from each of these isolates have been examined previously and have been shown to be different (Davies et al., 1991).

Bacteria, stored at $-70^{\circ} \mathrm{C}$ in brain heart infusion broth (BHIB) containing $50 \%(\mathrm{v} / \mathrm{v})$ glycerol, were routinely subcultured on brain heart infusion agar (BHIA) containing $5 \%(\mathrm{v} / \mathrm{v})$ sheep's blood at $37^{\circ} \mathrm{C}$. For the isolation of outer membranes and for growth studies bacteria were grown in BHIB in the absence or presence of $2,2^{\prime}$-dipyridyl, EDDA, ovotransferrin, bovine transferrin (Sigma) or desferal (CIBA Laboratories), as well as in decomplemented $\left(56^{\circ} \mathrm{C}\right.$ for $\left.20 \mathrm{~min}\right)$ foetal or newborn calf sera (Gibco) at $37^{\circ} \mathrm{C}$ with orbital shaking at 120 r.p.m. For the preparation of outer membranes optimum concentrations of chelating agents were determined from growth-rate experiments where growth, in the presence of increasing concentrations of chelating agent, was followed spectrophotometrically at $660 \mathrm{~nm}$. To confirm that inhibition of growth was, in fact, due to iron limitation, growth was also followed in the presence of an inhibitory concentation of EDDA or ovotransferrin and increasing concentrations of $\mathrm{FeCl}_{3}$. Outer membranes were also obtained from cells grown under conditions where the 


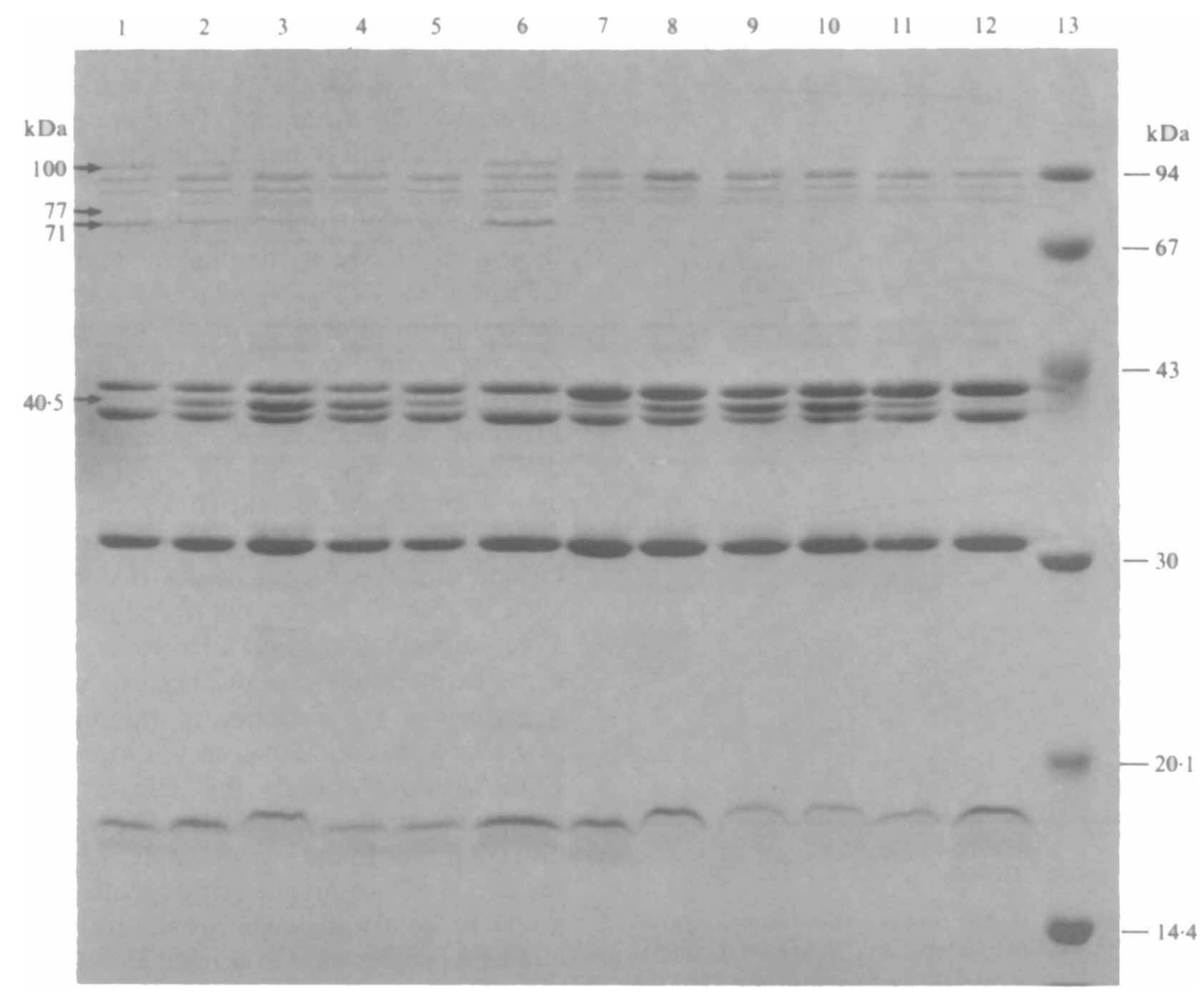

Fig. 3. OMP profiles of isolates S/C 82/1 (lanes 1-6) and W/D 83/4 (lanes 7-12) after growth to early stationary phase with no aeration (lanes 1 and 7), low aeration (lanes 2 and 8 ), high aeration (lanes 3 and 9), very high aeration (lanes 4 and 10 ), in $5 \% \mathrm{CO}_{2} / 95 \%$ air (lanes 5 and 11) and under anaerobic conditions (lanes 6 and 12). Molecular mass standards (lane 13) are phosphorylase b (94 kDa), bovine serum albumin $(67 \mathrm{kDa})$, ovalbumin $(43 \mathrm{kDa})$, carbonic anhydrase $(30 \mathrm{kDa})$, trypsin inhibitor $(20 \cdot 1 \mathrm{kDa})$ and $\alpha$-lactalbumin $(14 \cdot 4 \mathrm{kDa})$ (Pharmacia).

inhibitory effects of EDDA and ovotransferrin were eliminated by $\mathrm{FeCl}_{3}$, as well as from cells grown in foetal or newborn calf sera to which the same amount of $\mathrm{FeCl}_{3}$ had been added.

Growth under various degrees of aeration was examined by varying the broth : flask volume ratios, by using dimpled or smooth flasks, or by covering the surface of static cultures with liquid paraffin, as follows: $50 \mathrm{ml}$ of broth in $250 \mathrm{ml}$ dimpled conical flask (very high aeration); $50 \mathrm{ml}$ in $250 \mathrm{ml}$ smooth conical flask (high aeration); $100 \mathrm{ml}$ in $250 \mathrm{ml}$ smooth conical flask (moderate aeration) ; $200 \mathrm{ml}$ in $250 \mathrm{ml}$ smooth conical flask (low aeration) (all shaken at 120 r.p.m.); and $200 \mathrm{ml}$ in $250 \mathrm{ml}$ smooth conical flask covered with liquid paraffin and grown statically (no aeration). For outer membrane preparations, $500 \mathrm{ml}$ volumes were used in 2 litre dimpled flasks (very high aeration), 2 litre smooth flasks (high aeration), $500 \mathrm{ml}$ smooth flasks (low aeration) (all shaken), and in $500 \mathrm{ml}$ smooth flasks covered with liquid paraffin and grown statically (no aeration). Bacteria were also grown, in BHIB, in a $5 \% \mathrm{CO}_{2} / 95 \%$ air atmosphere in a controlled environment incubator shaker (New Brunswick Scientific) at 120 r.p.m. as well as anaerobically, using an anaerobe jar in conjunction with an anaerobe gas generating kit (Oxoid). In all experiments, flasks were inoculated from an overnight culture in BHIB to give a dilution of $1: 500$.
Preparation of outer membranes. Outer membranes were obtained by Sarkosyl extraction, essentially as described previously (Davies, 1991). At an appropriate stage of growth, bacteria were harvested, washed twice in $20 \mathrm{mM}$-Tris/ $\mathrm{HCl}(\mathrm{pH} \mathrm{7.2)}$ buffer, resuspended in the same buffer and sonicated, on ice, for $5 \mathrm{~min}$ (MSE sonicator; 4-5 $\mu \mathrm{m}$ amplitude; $20 \mathrm{kHz}$ ). Unbroken cells were removed by centrifugation $\left(10000 \mathrm{~g}\right.$ for $30 \mathrm{~min}$ at $4{ }^{\circ} \mathrm{C}$ ), cell envelopes pelleted by centrifugation at $60000 \mathrm{~g}$ for $1 \mathrm{~h}$ at $4{ }^{\circ} \mathrm{C}$, and cytoplasmic membranes solubilized by resuspending in $0.5 \%$ sodium $N$-lauroylsarcosine (Sarkosyl) for $20 \mathrm{~min}$ at room temperature (Filip et al., 1973). Outer membranes were pelleted by centrifugation at $60000 \mathrm{~g}$ for $1 \mathrm{~h}$, washed once in $20 \mathrm{~mm}-\mathrm{Tris} / \mathrm{HCl}(\mathrm{pH} \mathrm{7.2)}$, centrifuged again at $60000 \mathrm{~g}$ for $1 \mathrm{~h}$, resuspended in the same buffer to a protein concentration of $2.0 \mathrm{mg} \mathrm{ml}^{-1}$ and stored at $-70^{\circ} \mathrm{C}$.

Protein assay. Protein concentrations of outer membrane samples were assayed by the modified Lowry procedure of Markwell $e t$ al. (1978), a method suitable for insoluble membrane proteins.

Preparation of lipopolysaccharide. Lipopolysaccharide was obtained by proteinase K digestion as described by Hitchcock \& Brown (1983), except that outer membranes were the starting material rather than 


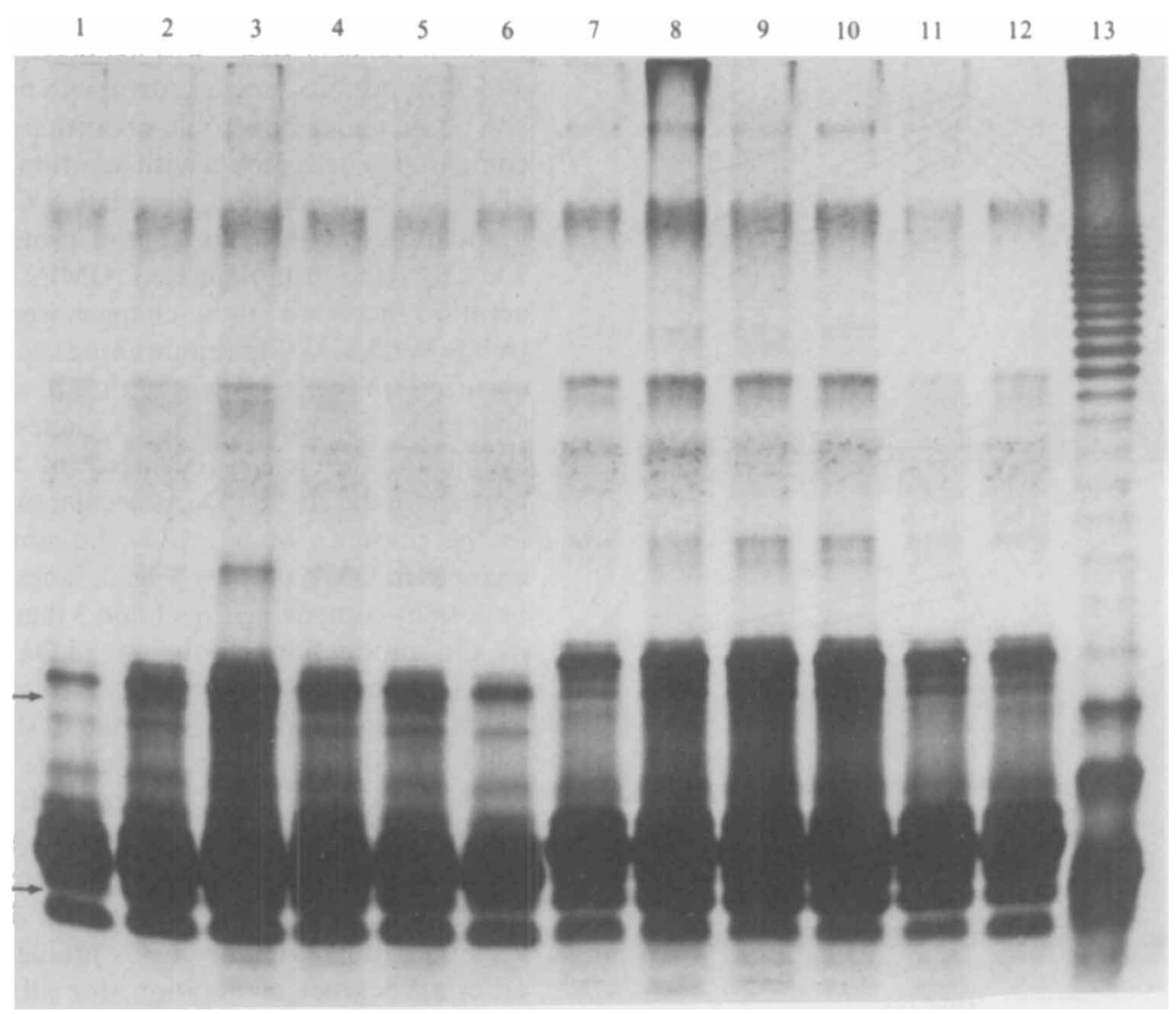

Fig. 4. LPS profiles of isolates S/C 82/1 (lanes 1-6) and W/D 83/4 (lanes 7-12) after growth under the conditions described in Fig. 3. LPS of $E$. coli B4 $(\mathrm{O}: 111)$ is shown in lane 13. Arrows indicate differences in low-molecular-mass regions (see text).

whole cells (Davies et al., 1991). Outer membranes $(2.0 \mathrm{mg}$ protein $\left.\mathrm{ml}^{-1}\right)$ were added to an equal volume of $\times 2$ sample buffer $(0.25 \mathrm{M}-$ Tris $/ \mathrm{HCl}, \mathrm{pH} 6.8,40 \%, \mathrm{v} / \mathrm{v}$, glycerol, $8 \%, \mathrm{w} / \mathrm{v}$, SDS, $0.2 \%, \mathrm{v} / \mathrm{v}$, 2-mercaptoethanol, $0.005 \%$, w/v, bromophenol blue) and heated at $100^{\circ} \mathrm{C}$ for $5 \mathrm{~min}$. To $100 \mu \mathrm{g}$ of protein were added $25 \mu \mathrm{g}$ of proteinase $\mathrm{K}$ (type XI protease; Sigma), adjusted to $2.5 \mathrm{mg} \mathrm{m}^{-1}$ in $\times 1$ sample buffer, and the mixture heated at $60{ }^{\circ} \mathrm{C}$ for $1 \mathrm{~h}$.

SDS-PAGE. OMPs and LPS were separated by SDS-PAGE using the SDS discontinuous system of Laemmli (1970). After stacking in a $4 \%(\mathrm{w} / \mathrm{v})$ gel, OMPs and LPS were separated in 12 and $15 \%(\mathrm{w} / \mathrm{v})$ resolving gels, respectively, the latter also containing $4 \mathrm{M}$-urea (Davies et al., 1991). A total of $25 \mu \mathrm{g}$ protein was loaded per lane $(25 \mu \mathrm{l})$, and $6 \mu \mathrm{l}$ of the same proteinase-K-treated samples for LPS (approximately $5 \mu \mathrm{g}$ LPS). Electrophoresis was performed in buffer comprising $25 \mathrm{~mm}$ Tris/ $\mathrm{HCl}, 192 \mathrm{mM}$-glycine and $0.1 \% \mathrm{SDS}(\mathrm{pH} 8.3$ ), at a constant current of $20 \mathrm{~mA}$ per gel through the stacking gel and $30 \mathrm{~mA}$ per gel through the resolving gel. Proteins were visualized by staining with Coomassie blue, and LPS by silver-staining (Tsai \& Frasch, 1978). Smooth lipopolysaccharide from $E$. coli B4 (O:111; Sigma) was used as a control for LPS.

\section{Results}

The OMP profiles of the two $P$. haemolytica isolates, $\mathrm{S} / \mathrm{C}$ $82 / 1$ and W/D 83/4, were very similar and comprised four or five major proteins and at least twenty minor proteins (Fig. 1). When cells were harvested at various stages of the growth cycle, i.e after 3.5, 6.5, 12 and $24 \mathrm{~h}$ of growth, under high aeration (see below), there was, in both isolates, a slight decrease in expression of a $40.5 \mathrm{kDa}$ protein and an increase in expression of a $18 \mathrm{kDa}$ protein, between exponential $(3.5 \mathrm{~h})$ and stationary $(6.5 \mathrm{~h})$ phases. In addition, in both isolates, a $24 \mathrm{kDa}$ protein was produced during the stationary phase but not during the exponential phase and, in $\mathrm{S} / \mathrm{C} 82 / 1$, a $94 \mathrm{kDa}$ protein was produced in greater abundance during the exponential phase (Fig. 1). In other strains examined (results not shown) there were additional differences between exponential and stationary phase cells that were not observed in the two isolates described here. Differences in banding patterns in the high-molecularmass region of the LPS of both isolates, between exponential and stationary phase cells, also occurred and have been described previously (Davies et al., 1991). To avoid variation in OMP or LPS profiles, as a result of cells being at different stages of growth, for all subsequent work bacteria were harvested during early stationary phase. 

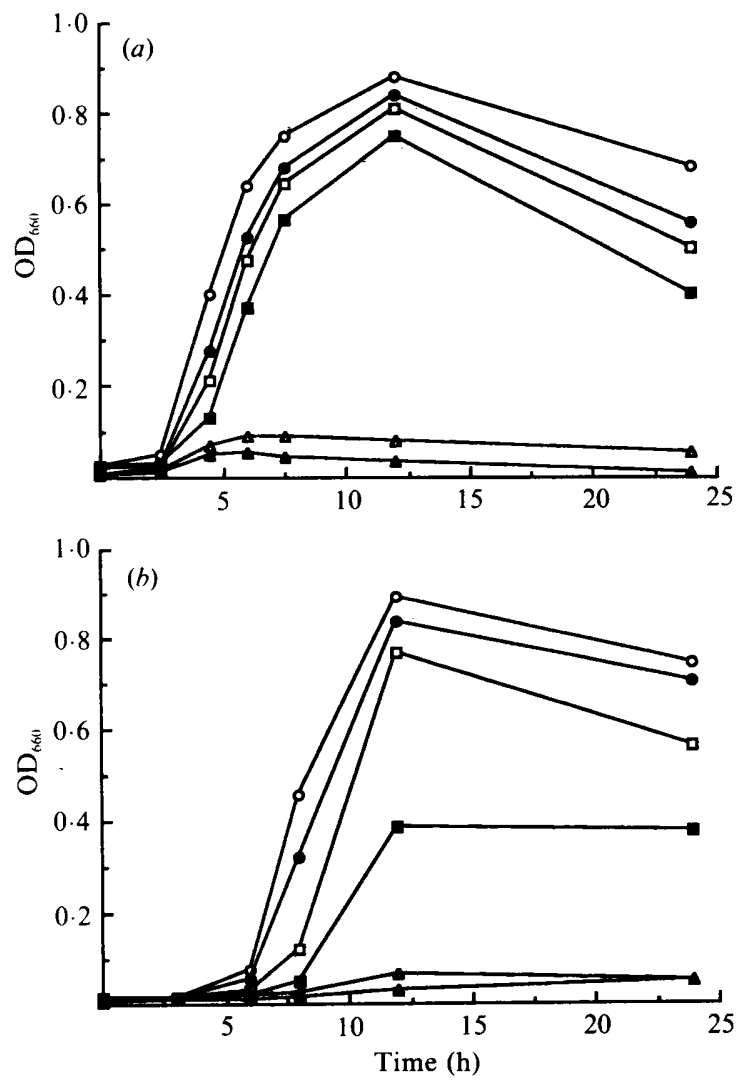

Fig. 5. Growth curves of isolate S/C $82 / 1$ in BHIB in the absence or presence of various concentrations of the chelators desferal $(a)$ or ovotransferrin $(b)$. Concentrations of desferal used were $0(O), 20(\bullet)$, $21.5(\square), 23(\square), 24.5(\Delta)$ and $26(\Delta) \mu \mathrm{M}$; concentrations of ovotransferrin used were $0(0), 0.5(\bullet), 0.75(\square), 1.0(\square), 1.25(\triangle)$ and $1.50(\Delta) \mathrm{mg} \mathrm{ml}^{-1}$.

The degree of aeration significantly affected the final cell density of the two isolates examined but, with the exception of no aeration, had a less significant affect on the growth rate (Fig. 2a). Generally, high aeration resulted in a high final cell density and as the degree of aeration decreased so did the final cell density; optimum cell density was not necessarily achieved, however, with maximum aeration, as was the case with isolate $S / C ~ 82 / 1$. With no aeration, the growth rate and final cell density, in both isolates, were substantially lower than under the other conditions. In the presence of $5 \% \mathrm{CO}_{2}$ there was a shorter lag phase but the growth rate during the exponential phase was similar to that in air alone; the final cell density was reduced in the presence of $5 \% \mathrm{CO}_{2}$ compared to that in air alone (Fig. 2b). Similar results were obtained with both isolates. Differences were also apparent in the OMP profiles of cells grown under the various conditions of aeration and $\mathrm{CO}_{2}$ tension (Fig. 3).
In both isolates there was reduced expression of the $40.5 \mathrm{kDa}$ protein in cells grown with no aeration (lanes 1 and 7) or under anaerobic conditions (lanes 6 and 12) compared to cells grown with aeration or in the presence of $5 \% \mathrm{CO}_{2}$. In addition, in isolate $\mathrm{S} / \mathrm{C} 82 / 1$, there was a gradual decline in expression of proteins of 71,77 and $100 \mathrm{kDa}$ (the iron-regulated OMPs - see below) as aeration increased; these changes were not observed in isolate W/D 83/4. Maximum expression of these proteins occurred in cells grown with no aeration or under anaerobic conditions (Fig. 3, lanes 1 and 6). Less significant differences occurred in the expression of proteins in the 20-26 kDa molecular mass range. Growth in the presence of $5 \% \mathrm{CO}_{2}$ did not yield significant changes in OMP profiles (Fig. 3, lanes 5 and 11). As can be seen by comparing Figs 1 and 3 there were differences in the production of the $40.5 \mathrm{kDa}$ protein in cells prepared on different occasions. The reasons for this are unknown but may have been due to slight differences in culture medium, aeration or sample preparation. The LPS profiles of cells grown with no aeration or anaerobically also differed from cells grown aerobically; these differences occurred in the low-molecular-mass region and are shown arrowed in Fig. 4. To avoid variation in OMP or LPS profiles resulting from differing degrees of aeration, for all subsequent work bacteria were grown with high aeration, i.e. a flask : culture ratio of $4: 1$, and at 120 r.p.m.

Growth of both strains was examined in the presence of increasing concentrations of the chelating agents $2,2^{\prime}$ dipyridyl, EDDA, desferal, ovotransferrin and bovine transferrin. In the case of each of these chelating agents, growth of both strains was rapidly slowed and inhibited within a very narrow range of concentration (Fig. 5). For example, growth was slowed and completely inhibited within the concentration ranges 100-140 (S/C 82/1), 15-22.5 and 20-24.5 $\mu \mathrm{M}$, for 2,2'-dipyridyl, EDDA and desferal, respectively. To obtain sufficient cells for outer membrane preparation, a concentration of chelating agent was chosen that gave significant growth-rate reduction, indicating iron-limited conditions, but which still resulted in relatively high cell numbers. Thus, 120 (S/C 82/1) or 150 (W/D 83/4) $\mu \mathrm{M}$-2,2'-dipyridyl, $19 \mu \mathrm{M}$ EDDA, $22 \mu \mathrm{M}$-desferal, $0.8 \mathrm{mg}$ ovotransferrin $\mathrm{ml}^{-1}$ or $1.25 \mathrm{mg}$ bovine transferrin $\mathrm{ml}^{-1}$ were used. OMP profiles of cells grown in the presence of these chelating agents were compared with those of cells grown in BHIB alone, and of cells grown in foetal or newborn calf sera. In all cases cells were harvested during early stationary phase, i.e. after approximately $7-8 \mathrm{~h}$ of growth. The complete OMP profiles of isolate $S / C ~ 82 / 1$ grown under the various conditions are shown in Fig. 6, whereas the highmolecular-mass regions of both isolates are compared in Fig. 7. There were significant differences in the 


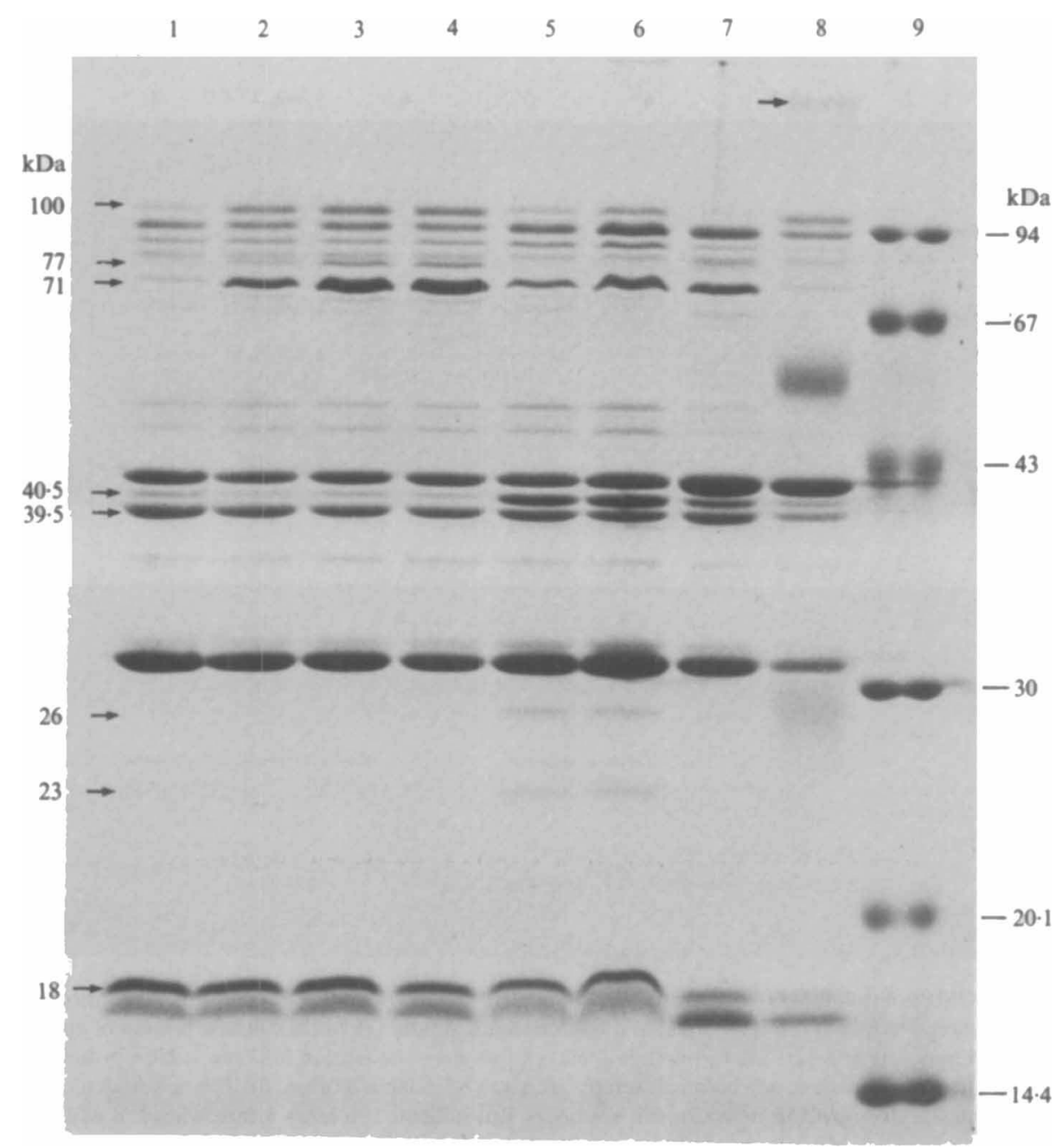

Fig. 6. OMP profiles of isolate S/C 82/1 after growth to stationary phase and with high aeration in BHIB (lane 1 ), BHIB $+120 \mu \mathrm{M}-2,2^{\prime}-$ dipyridyl (lane 2), BHIB $+19 \mu \mathrm{M}$-EDDA (lane 3), BHIB $+22 \mu \mathrm{M}$-desferal (lane 4), BHIB $+0.8 \mathrm{mg}$ ovotransferrin $\mathrm{ml}^{-1}$ (lane 5), BHIB $+1.25 \mathrm{mg}$ bovine transferrin $\mathrm{ml}^{-1}$ (lane 6), foetal calf serum (lane 7) and newborn calf serum (lane 8). The high-molecular-mass protein (see text) is shown arrowed in lane 8. Molecular mass standards (lane 9) were identical to those in Fig. 3.

expression of the three recognized iron-regulated OMPs as well as in other OMPs after growth in the various media. Growth in the presence of 2,2'-dipyridyl, EDDA or desferal gave identical results for each isolate. There were similar increases in the expression of the 71,77 and $100 \mathrm{kDa}$ proteins in the case of isolate $\mathrm{S} / \mathrm{C} 82 / 1$ and of the 71 and $100 \mathrm{kDa}$ proteins in the case of isolate W/D 83/4; production of the $77 \mathrm{kDa}$ protein did not, however, increase in isolate $\mathrm{W} / \mathrm{D} 83 / 4$.

In the presence of ovotransferrin and bovine transferrin different results were obtained. Although expression of the $71 \mathrm{kDa}$ protein clearly increased in both isolates, expression of the $100 \mathrm{kDa}$ protein was only slightly enhanced in both isolates, whereas there was no expression of the $77 \mathrm{kDa}$ protein in either isolate; this was particularly noticeable in isolate $\mathrm{S} / \mathrm{C} 82 / 1$.
Expression of both the 71 and $100 \mathrm{kDa}$ proteins was greater in the presence of bovine transferrin than in the presence of ovotransferrin, the latter chelator increasing production of the $100 \mathrm{kDa}$ protein very little, if at all. In addition, in both isolates, there was increased production of the $40.5 \mathrm{kDa}$ protein, as well as synthesis of two new proteins of 23 and $26 \mathrm{kDa}$ after growth in the presence of these two chelators. Once again, there were differences in the expression of the $40.5 \mathrm{kDa}$ protein between cells grown on different occasions but under the same conditions (compare Figs 3 and 6).

Further differences were observed after growth in foetal and newborn calf sera. In foetal calf serum there was, in both isolates, enhanced expression of the $71 \mathrm{kDa}$ protein but not of the $100 \mathrm{kDa}$ protein. There was no enhanced expression of the $77 \mathrm{kDa}$ protein in isolate 

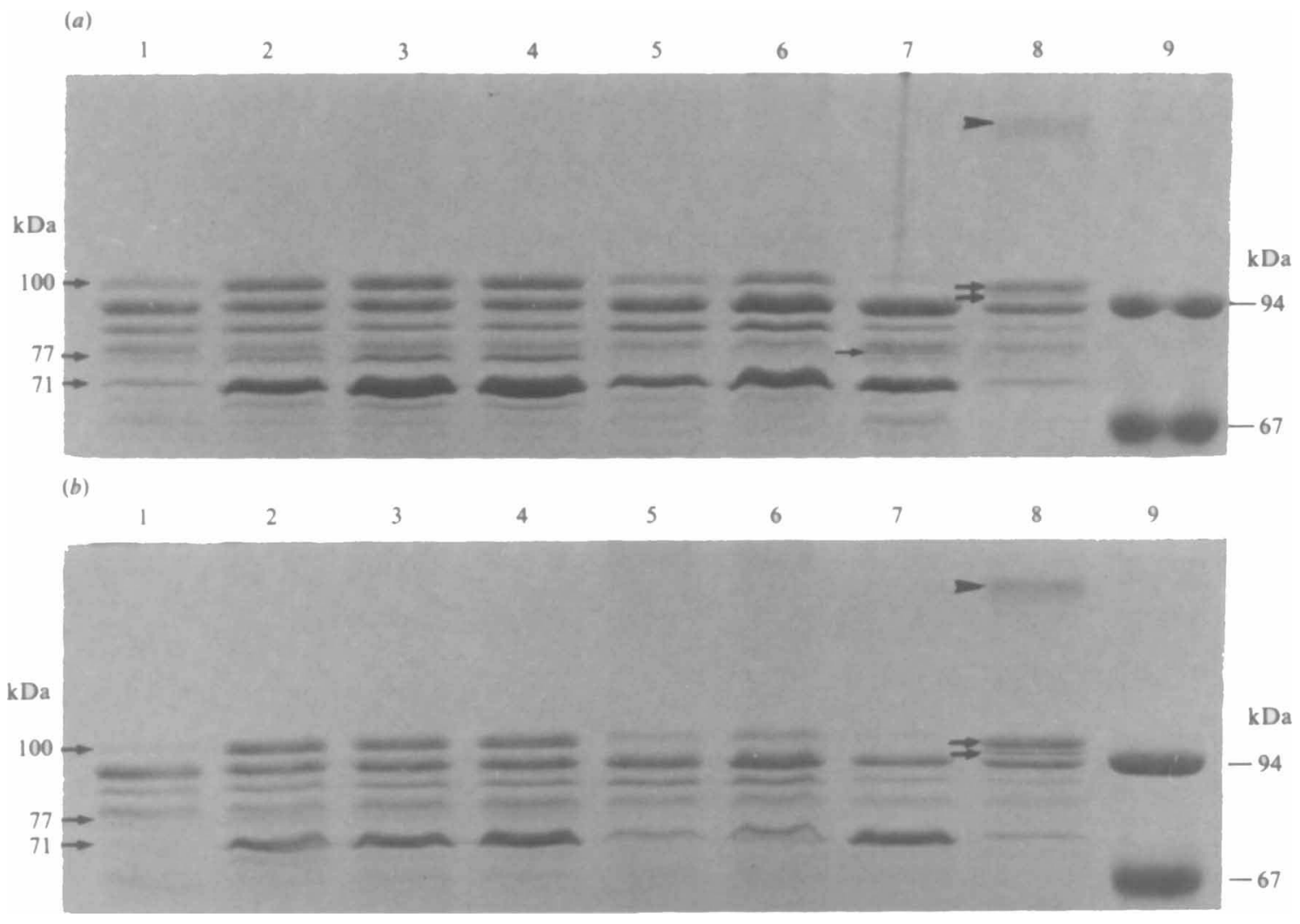

Fig. 7. Iron-regulated OMPs of isolate S/C 82/1 (a) and W/D 83/4 (b) after growth under the conditions described in Fig. 5. Molecular mass markers (lane 9) were phosphorylase b $(94 \mathrm{kDa})$ and bovine serum albumin $(67 \mathrm{kDa})$. A new protein of approximate molecular mass $78 \mathrm{kDa}$ expressed in isolate S/C 82/1 after growth in foetal calf serum is arrowed in (a), lane 7 . New proteins of 97 and $98 \mathrm{kDa}$, expressed in both isolates after growth in newborn calf serum, are arrowed in lanes $8(a$ and $b)$. The new high molecular mass protein, expressed in both isolates after growth in newborn calf serum, is also indicated in lanes 8 (arrowhead, $a$ and $b$ ).

$\mathrm{S} / \mathrm{C} 82 / 1$, and no expression at all in isolate $\mathrm{W} / \mathrm{D} 83 / 4$; an additional protein was synthesized in this region in isolate $\mathrm{S} / \mathrm{C} 82 / 1$ (Fig. $7 a$, lane 7 , arrowed). In newborn calf serum there was, in both isolates, expression of a protein of apparent molecular mass slightly less than the $100 \mathrm{kDa}$ protein (about $98 \mathrm{kDa}$ ). Also, in both isolates, there was no enhanced expression of the $71 \mathrm{kDa}$ protein, and the $77 \mathrm{kDa}$ protein was not produced. In addition, in both isolates, there was synthesis of a novel highmolecular-mass protein as well as an additional protein of apparent molecular mass $97 \mathrm{kDa}$; expression of 18 and $39.5 \mathrm{kDa}$ proteins was reduced. Two diffuse protein bands of approximate molecular masses 28 and $52 \mathrm{kDa}$ were also present, in both isolates, after growth in newborn calf serum; these proteins were not present in cells grown in foetal calf serum or under any of the other growth conditions. There were no significant differences in the LPS profiles of cells grown under the various conditions, although there did appear to be less LPS produced, in proportion to outer-membrane protein, in the foetal- and newborn-calf-sera-grown cells (Fig. 8).
The effects of addition of $100 \mu \mathrm{M}-\mathrm{FeCl}_{3}$ to BHIB containing $50 \mu \mathrm{M}$-EDDA or $2 \mathrm{mg}$ ovotransferrin $\mathrm{ml}^{-1}$, or to foetal or newborn calf sera, on the expression of OMPs in isolate $\mathrm{S} / \mathrm{C} 82 / 1$ are shown in Fig. 9. The $\mathrm{FeCl}_{3}$ repressed the 71,77 and $100 \mathrm{kDa}$ proteins induced by the EDDA and caused reduced expression of the 40.5 and $71 \mathrm{kDa}$ proteins, repression of the 23 and $26 \mathrm{kDa}$ proteins and normal synthesis of the $77 \mathrm{kDa}$ protein in the presence of ovotransferrin. Addition of $100 \mu \mathrm{M}-\mathrm{FeCl}_{3}$ to newborn calf serum did not cause repression of the $98 \mathrm{kDa}$ protein and caused no change to expression of the 71 and $77 \mathrm{kDa}$ proteins, which were expressed to the same extent as in BHIB alone. Furthermore, there was no change in the expression of the high-molecular-mass protein. Addition of $\mathrm{FeCl}_{3}$ to foetal calf serum caused a marked reduction in the expression of the $71 \mathrm{kDa}$ protein. Interestingly, there was slight induction of the high-molecular-mass protein after addition of $\mathrm{FeCl}_{3}$ to foetal calf serum. Similar results were obtained for isolate W/D 83/4 after growth in the presence of EDDA or ovotransferrin and $\mathrm{FeCl}_{3}$. 


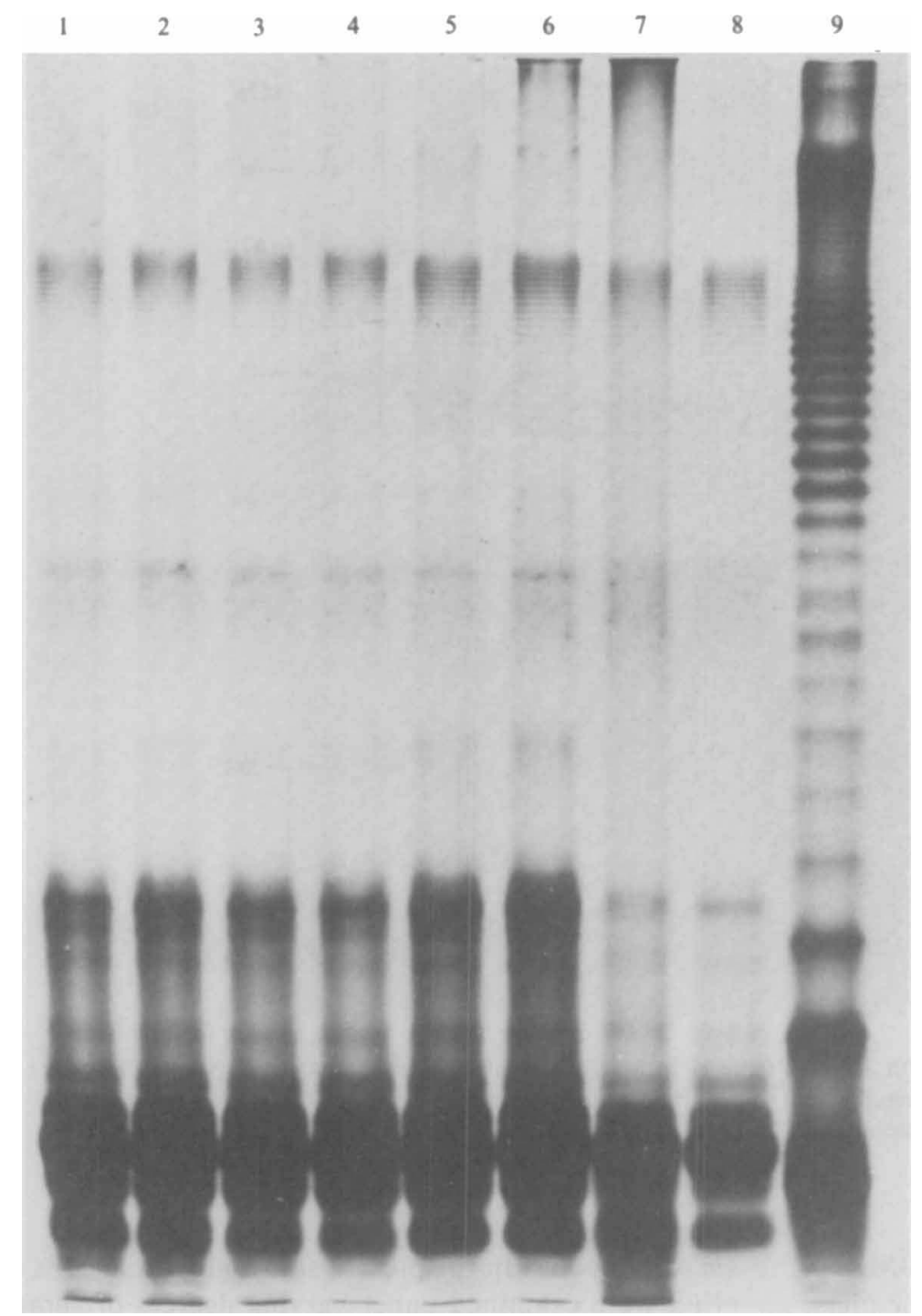

Fig. 8. LPS profiles of isolate $\mathrm{S} / \mathrm{C} 82 / 1$ after growth under the conditions described in Fig. 6. Samples were standardized with respect to the protein content of the outer membrane (see text). LPS of E. coli B4 $(0: 111)$ is shown in lane 9.

\section{Discussion}

The OMP profiles of the two $P$. haemolytica isolates, SC $82 / 1$ and WD 83/4, were very similar and comprised four or five major proteins and at least twenty minor proteins (Fig. 1). Proteins of apparent molecular masses 18, 29, $39.5,40.5$ and $42 \mathrm{kDa}$ could be classed as major proteins, the last three being in the same molecular mass range as the porin proteins of $E$. coli and other members of the Enterobacteriaceae (Lugtenberg et al., 1977). Proteins in the molecular mass range 70-100 $\mathrm{kDa}$ included the 71, 77 and $100 \mathrm{kDa}$ iron-regulated proteins of $P$. haemolytica previously described by others (Donachie \& Gilmour, 1988; Deneer \& Potter, 1989; Ogunnariwo \& Schryvers, 1990).

Variation in OMP profiles at different stages of the growth cycle probably reflects changes in nutrient availability at the different growth stages, although changes due to differences in growth rate per se cannot be discounted (Brown \& Williams, 1985). It is important to note, furthermore, that changes due to nutrient depletion can actually occur three cell divisions before the onset of stationary phase (Brown \& Williams, 1985). In the present study, clear differences in the expression of certain minor OMPs occurred between exponential and stationary phase cells and were, most likely, due to specific nutrient depletion. However, minor proteins, as differentiated by Coomassie blue staining of SDSpolyacrylamide gels, may be more immunogenic than major proteins and appear as dominant bands when analysed by Western blotting (Davies et al., 1990). Such differences in expression of minor proteins may also occur in vivo and may be very important in terms of the success or failure of the organism to survive and produce 


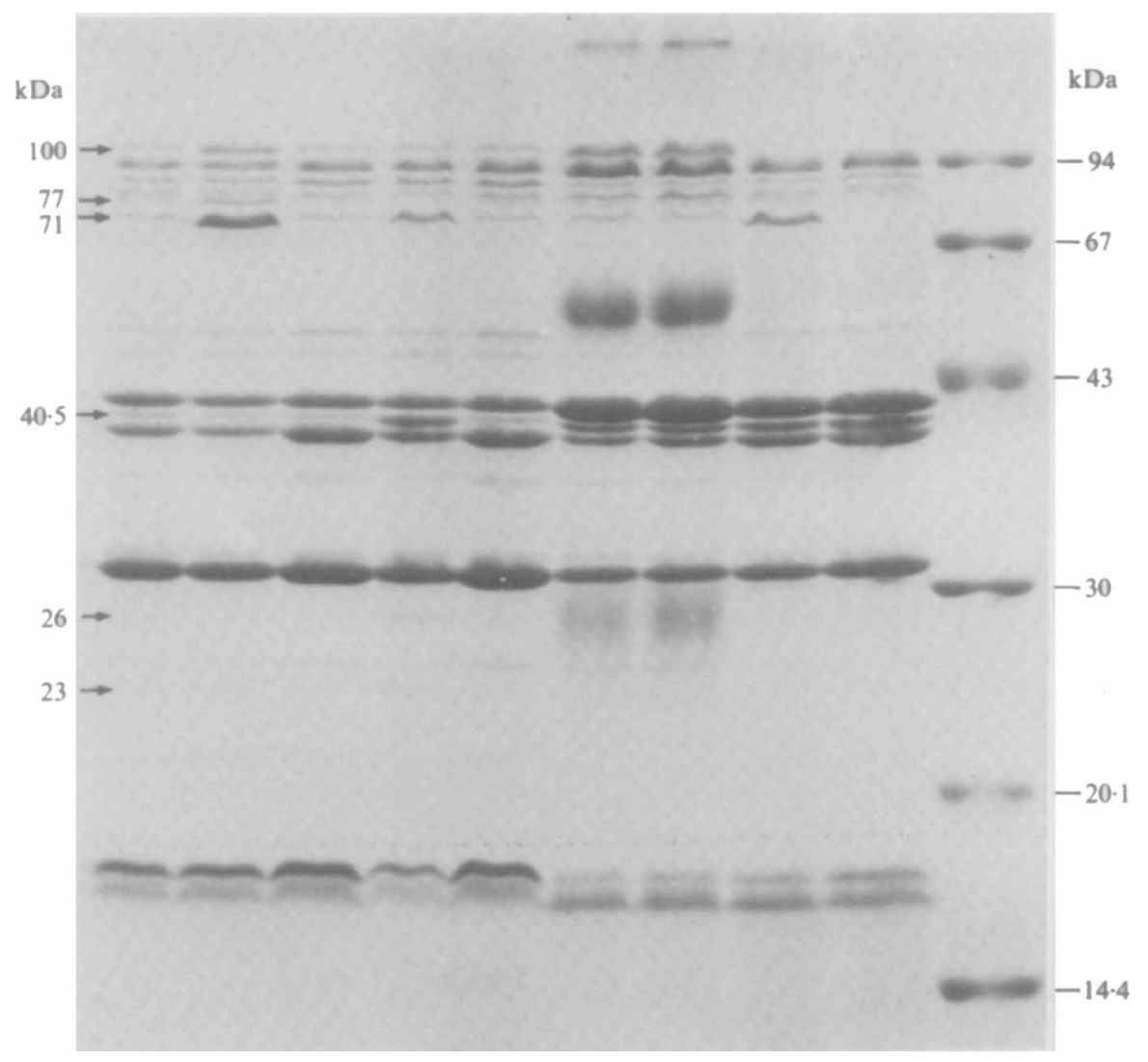

Fig. 9. OMP profiles of isolate S/C 82/1 after growth in BHIB (lane 1), in BHIB containing $50 \mu \mathrm{M}-\mathrm{EDDA}$ (lanes 2 and 3 ) or $2 \mathrm{mg}$ ovotransferrin $\mathrm{ml}^{-1}$ (lanes 4 and 5), in newborn calf serum (lanes 6 and 7) or in foetal calf serum (lanes 8 and 9). Cells were grown in the absence of added iron (lanes 2, 4, 6 and 8) or in the presence of $100 \mu \mathrm{M}-\mathrm{FeCl}_{3}$ (lanes 3, 5, 7 and 9). Molecular mass standards (lane 10) were identical to those shown in Fig. 3.

disease. There were no obvious changes in the OMPs of cells as growth progressed from early stationary phase $(6.5 \mathrm{~h})$ to late stationary phase $(24 \mathrm{~h})$ thus indicating that the critical period for changes in the expression of certain OMPs was between the exponential phase and early stationary phase.

Growth of Salmonella spp. under oxygen-limited conditions has been demonstrated to cause repression of an outer-membrane protein (Schiemann \& Shope, 1991) or increased synthesis of certain proteins (Lee \& Falkow, 1990), these latter changes in turn leading to an increase in invasiveness. At least three novel OMPs are induced in $N$. gonorrhoeae when grown anaerobically (Clark et al., 1987), one of these being a major antigen recognized by patients' sera (Clark et al., 1988). In a comparison of coagulase-negative staphylococci grown in air or in air containing $5 \% \mathrm{CO}_{2}$, Denyer et al. (1990) demonstrated significant differences in surface-exposed carbohydrates and proteins, as well as changes in cell-wall protein profiles and adherence, and concluded that the in vivo gaseous tension is an important factor to be considered in in vitro models. In the present study, growth, OMPs and LPS were examined under varying degrees of aeration and in an atmosphere of $5 \% \mathrm{CO}_{2} / 95 \%$ air. In general, with the exception of anaerobic growth, the growth rate was not greatly affected by the degree of aeration, whereas the final cell density was significantly affected. In the presence of $\mathrm{CO}_{2}$, initial growth was more rapid although the final cell density was less than the corresponding growth in air. Although the presence of $\mathrm{CO}_{2}$ did not significantly affect the OMP profiles, the degree of aeration affected a number of minor proteins as well as the $40.5 \mathrm{kDa}$ major protein. Synthesis of this latter protein was significantly reduced after growth under anaerobic conditions. The enhanced expression of the 71,77 and $100 \mathrm{kDa}$ proteins under anaerobic conditions, and their reduced expression as aeration increased, in isolate $S / C 82 / 1$, was also significant and suggested that these proteins may be regulated by oxygen as well as by iron. This phenomenon, which has not been described before, did not occur in isolate W/D 83/4, and deserves further attention. 
The growth patterns of the two isolates in the presence of the various chelators were unexpected in that growth was rapidly slowed and completely inhibited within a very narrow range of chelator concentration. In additional experiments (results not shown), the inhibitory effects of $50 \mu \mathrm{M}$-EDDA and $2 \mathrm{mg}$ ovotransferrin $\mathrm{ml}^{-1}$ were overcome by similar small incremental increases in $\mathrm{FeCl}_{3}$ concentration. For example, $25 \mu \mathrm{M}-\mathrm{FeCl}_{3}$ had no effect on inhibition whereas $50 \mu \mathrm{M}-\mathrm{FeCl}_{3}$ completely restored growth of both isolates in the presence of $50 \mu \mathrm{M}$ EDDA. These results suggest that growth of $P$. haemolytica is finely regulated by micromolar concentrations of iron.

The variation in expression of different OMPs in the presence of the various chelators and in foetal and newborn calf sera was highly significant. In terms of their effects on the induction of various OMPs, the chelators could be divided into two groups, Group 1 consisting of 2,2'-dipyridyl, EDDA and desferal, and Group 2 consisting of ovotransferrin and bovine transferrin. Whereas the Group 1 chelators caused significant increases in the 71,77 and $100 \mathrm{kDa}$ proteins, as has been described previously (Deneer \& Potter, 1989), the Group 2 chelators induced increases in the 71 and 100 (less marked) $\mathrm{kDa}$ proteins but not of the $77 \mathrm{kDa}$ protein. In addition, there was increased production of the $40.5 \mathrm{kDa}$ protein and synthesis of two additional proteins, of 23 and $26 \mathrm{kDa}$, after growth in the presence of Group 2 chelators. Increased synthesis of the 71 and $100 \mathrm{kDa}$ proteins was slightly greater in SC 82/1 than in WD 83/4. Furthermore, the increase in synthesis of the $100 \mathrm{kDa}$ protein in particular was not as great for the Group 2 chelators as it was for the Group 1 chelators. Since previous investigators have used only 2,2 '-dipyridyl, EDDA or desferal in iron-limitation experiments with $P$. haemolytica (Donachie \& Gilmour, 1988; Deneer \& Potter, 1989; Ogunnariwo \& Schryvers, 1990; Lainson et al., 1991) these observations are highly significant because they suggest that results obtained with Group 1 chelators may not be strictly representative of the in vivo situation. In contradiction to the observation of Deneer \& Potter (1989) that the $77 \mathrm{kDa}$ protein was completely absent from iron-replete cells, whereas the 71 and $100 \mathrm{kDa}$ proteins were detectable in iron-replete cells, this study demonstrated that all three proteins were present in iron-replete cells and that their synthesis was increased individually by specific and different conditions. The study also demonstrated that the increased synthesis of the $77 \mathrm{kDa}$ protein in the presence of the Group 1 chelators may be strain dependent. This would explain the failure to detect this protein in an A2 strain of $P$. haemolytica grown under iron-limitation by Donachie \& Gilmour (1988).

Further differences occurred in the expression of
OMPs during growth in foetal and newborn calf sera. Expression of the 77 and $100 \mathrm{kDa}$ proteins was not increased, compared to that in BHIB, in either foetal calf serum or newborn calf serum. Although expression of the $71 \mathrm{kDa}$ protein was increased in foetal calf serum, compared to its expression in BHIB, and completely inhibited by the addition of $\mathrm{FeCl}_{3}$, it was expressed to the same extent as in BHIB in both neat and ironsupplemented newborn calf serum. These results suggest that foetal calf serum provides an iron-limited environment, and that the $71 \mathrm{kDa}$ protein is an iron-regulated OMP, but that the 77 and $100 \mathrm{kDa}$ proteins may not be important iron-regulated proteins, as the results with Group 1 chelators suggest (Deneer \& Potter, 1989). In particular, results with the Group 2 chelators and the animal sera suggest that the $77 \mathrm{kDa}$ protein may not be an important protein in vivo. These results support the findings of Donachie \& Gilmour (1988), in fact, who were not able to demonstrate synthesis of this protein in an A2 strain of $P$. haemolytica isolated directly from the lungs of an infected sheep, although Deneer \& Potter (1989) described synthesis of this protein in ironrestricted A2 cells grown in the presence of 2,2'dipyridyl. However, as explained above, these discrepancies may have been due to strain variation. It is also notable that the former workers were not able to demonstrate, by Western-blotting with serum from infected sheep, recognition of the $100 \mathrm{kDa}$ protein in the same in-vivo-obtained cells, although a faint band was present in a Coomassie-blue-stained SDS-polyacrylamide gel. The non-expression of the $100 \mathrm{kDa}$ protein, the receptor for bovine transferrin (Ogunnariwo \& Schryvers, 1990), within the detection limits of Coomassie blue staining at least, in either foetal calf serum or newborn calf serum was unexpected and suggests that the protein may not be produced in significant quantity in vivo and may not, therefore, be a good vaccine candidate. This may also help to explain the inability of Donachie \& Gilmour (1988) to detect this protein by Western blotting in in-vivo-obtained cells. Although the $71 \mathrm{kDa}$ protein was expressed in abundance in the presence of Group 2 chelators as well as in foetal calf serum, indicating its potential as a vaccine candidate, the non-expression of this protein in newborn calf serum raises questions against this possibility which need to be resolved. The results in newborn calf serum suggest that the medium is not iron-limiting, since none of the three previously recognized iron-regulated proteins were produced and addition of $\mathrm{FeCl}_{3}$ made no difference to the OMP profiles. However, in this medium, at least three additional OMPs were produced, one of which, the $98 \mathrm{kDa}$ protein is highly immunogenic (results not shown). The $98 \mathrm{kDa}$ protein, it should be pointed out, could easily be mistaken for the $100 \mathrm{kDa}$ 
protein. Confirmation of their being different proteins was achieved with monospecific polyclonal rabbit antisera raised against each of the proteins (results not shown). The apparent non-regulation of these three additional proteins by iron was unexpected and raises the question as to exactly what induces their synthesis. Reduction in expression of the $18 \mathrm{kDa}$ protein in cells grown in newborn calf serum was probably analogous to the reduced expression of a $17 \mathrm{kDa}$ protein observed in A2 cells obtained from pleural fluid of a sheep, compared to those grown in artificial media, described by Donachie \& Gilmour (1988). This observation is significant because it indicates that the in vitro growth conditions for the $\mathrm{A} 1$ isolates in bovine sera, as described in the present study, are similar to the in vivo growth conditions for the A2 strain described by these authors. Identical results, it should be noted, were obtained with two different batches of foetal and newborn calf sera. The two diffuse protein bands of approximate molecular masses 28 and $52 \mathrm{kDa}$, which occurred in cells grown in newborn calf serum only, probably represented cellsurface-bound IgG light and heavy chains, respectively. Surface-bound IgG light and heavy chains have also been detected in in-vivo-grown E. coli (Finn et al., 1982) and $P$. haemolytica A2 (Sutherland et al., 1990). Bound serum albumin was not observed, however, as it has been for in-vivo-grown P. haemolytica A2 (Sutherland et al., 1990).

Although there was no variation in LPS profiles in the presence of various chelators, there was quantitative variation in LPS, relative to the amount of protein in the outer membrane, in cells grown in foetal and newborn calf sera compared to cells grown under other conditions. In addition, there were differences in the LPS of cells grown aerobically compared to cells grown anaerobically, as well as differences between exponential and stationary phase cells (Davies et al., 1991). Changes in LPS, due to differences in aeration, have also been described in N. meningitidis (Tsai et al., 1983). It might be expected from these observations, therefore, that there would be some quantitative differences in the LPS of cells that had been grown in vivo compared to cells grown in standard laboratory media. Although Sutherland et al. (1990) observed no differences in the LPS profiles of $P$. haemolytica cells grown in vivo compared to cells grown in vitro, their study was carried out with an A2 strain, possessing a rough-type LPS. Differences in the highmolecular-mass region of the LPS molecule, i.e. the O-antigen, may well occur between in-vivo- and in-vitrogrown Al cells.

In conclusion, this study has demonstrated significant differences in the synthesis of certain $P$. haemolytica OMPs under various growth conditions. In particular, the OMP profiles of cells grown in foetal or newborn calf sera are different to each other and to those of cells grown in the presence of artificial chelating agents. The study raises questions as to the use of these chelators and the conclusions derived from previous studies. Subtle differences were also observed in the LPS profiles of cells grown under various conditions. Finally, the study has highlighted the importance of examining the OMP and LPS profiles of cells grown in vivo and this work is currently underway.

This work was supported by grant AG17/529 from the Agricultural and Food Research Council.

\section{References}

Anwar, H., Brown, M. R. W., Day, A. \& Weller, P. H. (1984). Outer membrane antigens of mucoid Pseudomonas aeruginosa isolated directly from the sputum of a cystic fibrosis patient. FEMS Microbiology Letters 24, 235-239.

BanerJee-Bhatnagar, N. \& Frasch, C. E. (1990). Expression of Neisseria meningitidis iron-regulated outer membrane proteins, including a 70-kilodalton transferrin receptor, and their potential for use as vaccines. Infection and Immunity 58, 2875-2881.

BibersteIN, E. L. (1978). Biotyping and serotyping of Pasteurella haemolytica. Methods in Microbiology 10, 253-268.

Black, J. R., Dyer, D. W., Thompson, M. K. \& Sparling, P. F. (1986). Human immune response to iron-repressible outer membrane proteins of Neisseria meningitidis. Infection and Immunity 54, 710-713.

Blaser, M. J., Hopkins, J. A., Berka, R. M., Vasil, M. L. \& Wang, W.-L. L. (1983). Identification and characterization of Campylobacter jejuni outer membrane proteins. Infection and Immunity 42, 276-284.

Bolin, C. A. \& Jensen, A. E. (1987). Passive immunization with antibodies against iron-regulated outer membrane proteins protects turkeys from Escherichia coli septicaemia. Infection and Immunity 55, 1239-1242.

Brown, M. R. W. \& Williams, P. (1985). The influence of environment on envelope properties of bacteria in infections. Annual Review of Microbiology 39, 527-556.

Brown, M. R. W., ANWAR, H. \& Lambert, P. A. (1984). Evidence that mucoid Pseudomonas aeruginosa in the cystic fibrosis lung grows under iron-restricted conditions. FEMS Microbiology Letters 21, 113-117.

CARTER, G. R. (1967). Pasteurellosis: Pasteurella multocida and Pasteurella haemolytica. Advances in Veterinary Science 11, 321-379.

Chart, H., Buck, M., Stevenson, P. \& Griffiths, E. (1986). Iron regulated outer membrane proteins of Escherichia coli : variations in expression due to the chelator used to restrict the availability of iron. Journal of General Microbiology 132, 1373-1378.

Clark, V. L., Campbell, L. A., Palermo, D. A., Evans, T. E. \& KLIMPEL, K. W. (1987). Induction and repression of outer membrane proteins by anaerobic growth of Neisseria gonorrhoeae. Infection and Immunity 55, 1359-1364.

Clark, V. L., Knapp, J. S., Thompson, S. \& Klimpel, K. W. (1988). Presence of antibodies to the major anaerobically induced gonococcal outer membrane protein in sera from patients with gonococcal infections. Microbial Pathogenesis 5, 381-390.

Confer, A. W., Lessley, B. A., Panciera, R. J., Fulton, R. W. \& Rummage, J. A. (1985). Effect of vaccination with live or killed Pasteurella haemolytica on resistance to experimental bovine pneumonic pasteurellosis. American Journal of Veterinary Research 46, 342-347.

Confer, A. W., Panciera, R. J. \& Mosier, D. A. (1986). Serum antibodies to Pasteurella haemolytica lipopolysaccharide: relation- 
ship to experimental bovine pneumonic pasteurellosis. American Journal of Veterinary Research 47, 1134-1138.

Craven, R. C., Confer, A. W. \& Gentry, M. J. (1991). Cloning and expression of a $30 \mathrm{kDa}$ surface antigen of Pasteurella haemolytica. Veterinary Microbiology 27, 63-78.

Davies, R. L. (1991). Outer membrane protein profiles of Yersinia ruckeri. Veterinary Microbiology 26, 125-140.

Davies, R. L., WALl, R. A. \& BorRIELlo, S. P. (1990). Comparison of methods for the analysis of outer membrane proteins of Neisseria meningitidis by Western blotting. Journal of Immunological Methods 134, 215-225.

Davies, R. L., Ali, Q., Parton, R., Coote, J. G., Gibbs, A. H. \& FREER, J. H. (1991). Optimal conditions for the analysis of Pasteurella haemolytica lipopolysaccharide by sodium dodecyl sulphate-polyacrylamide gel electrophoresis. FEMS Microbiology Letters 90, 23-28.

Deneer, H. G. \& PotTer, A. A. (1989). Iron-repressible outer membrane proteins of Pasteurella haemolytica. Journal of General Microbiology 135, 435-443.

Denyer, S. P., Davies, M. C., Evans, J. A., Finch, R. G., Smith, D. G. E., WilcoX, M. H. \& Williams, P. (1990). Influence of carbon dioxide on the surface characteristics and adherence potential of coagulase-negative Staphylococci. Journal of Clinical Microbiology 28, 1813-1817.

DoNACHIE, W. \& GILmouR, N. J. L. (1988). Sheep antibody response to cell wall antigens expressed in vivo by Pasteurella haemolytica serotype A2. FEMS Microbiology Letters 56, 271-276.

Durham, J. A., Confer, A. W., Mosier, D. A. \& Lessley, B. A (1986). Comparison of the antigens associated with saline, potassium thiocyanate, and sodium salicylate extracts of Pasteurella haemolytica serotype 1. American Journal of Veterinary Research 47, 1946-1951.

Filip, C., Fletcher, G., Wulff, J. L. \& Earhart, C. F. (1973). Solubilization of the cytoplasmic membrane of Escherichia coli by the ionic detergent sodium lauryl sarcosinate. Journal of Bacteriology 115, 717-722.

Finn, T. M., Arbuthnott, J. P. \& Dougan, G. (1982). Properties of Escherichia coli in vivo using a chamber implant system. Journal of General Microbiology 128, 3083-3091

Frank, G. H. (1979). Pasteurella haemolytica and respiratory disease in cattle. Proceedings of the United States Animal Health Association 83, 153-160.

Fodor, L., Varja, J., Hajtos, J., Donachie, W. \& Gilmour, N. J. L. (1988). Characterization of a new serotype of $P$. haemolytica isolated in Hungary. Research in Veterinary Science 44, 399.

Gilmour, N. J. L., Angus, K. W., Donachie, W. \& Fraser, J. (1982). Vaccination against experimental pneumonic pasteurellosis. Veterinary Record 110, 450.

Gilmour, N. J. L., Donachie, W., Sutherland, A. D., Gilmour, J. S., JONES, G. E. \& QUIRIE, M. (1991). Vaccination containing ironregulated proteins of Pasteurella haemolytica A2 enhances protection against experimental pasteurellosis in lambs. Vaccine 9, 137-140.

Grifpiths, E., Stevenson, P. \& Joyce, P. (1983). Pathogenic Escherichia coli express new outer membrane proteins when growing in vivo. FEMS Microbiology Letters 16, 95-99.

Hitchcock, P. J. \& Brown, T. M. (1983). Morphological heterogeneity among Salmonella lipopolysaccharide chemotypes in silverstained polyacrylamide gels. Journal of Bacteriology 154, 269-277.

Kelly, J. T. \& PARKER, C. D. (1981). Identification and preliminary characterization of Vibrio cholerae outer membrane proteins. Journal of Bacteriology 145, 1018-1024.

Kelly, N. M., Bell, A. \& Hancock, R. E. W. (1989). Surface characteristics of Pseudomonas aeruginosa grown in a chamber implant model in mice and rats. Infection and Immunity 57, 344-350.

K NIGHTS, J. M., ADLAM, C. \& OWEN, P. (1990). Characterization of envelope proteins from Pasteurella haemolytica and Pasteurella multocida. Journal of General Microbiology 136, 495-505.

LAEMMLI, U. K. (1970). Cleavage of structural proteins during the assembly of the head of bacteriophage T4. Nature, London 227 , 680-685

Lainson, F. A., Harkins, D. C., Wilson, C. F., Sutherland, A. D., MURRAY, J. E., DonaChIE, W. \& BaIRD, G. D. (1991). Identification and localization of an iron-regulated $35 \mathrm{kDa}$ protein of Pasteurella haemolytica serotype A2. Journal of General Microbiology 137, 219-226.

LEE, C. A. \& FALKow, S. (1990). The ability of Salmonella to enter mammalian cells is affected by bacterial growth state. Proceedings of the National Academy of Sciences of the United States of America 87, 4304-4308.

Lesley, B. A., Confer, A. W., Mosier, D. A., Gentry, M. J., Durham, J. A. \& Rummage, J. A. (1985). Saline-extracted antigen of Pasteurella haemolytica: separation by chromatofocusing. Preliminary characterization and evaluation of immunogenicity. Veterinary Immunology and Immunopathology 10, 279-296.

LOEB, M. R. \& SMITH, D. H. (1980). Outer membrane protein composition in disease isolates of Haemophilus influenzae: pathogenic and epidemiological implications. Infection and Immunity 30, 709-717.

Lugtenberg, B., Bronstein, H., Van Selm, N. \& Peters, R. (1977). Peptidoglycan-associated outer membrane proteins in Gram-negative bacteria. Biochimica et Biophysica Acta 465, 571-578.

Mandrell, R. E., Lesse, A. J., Sugal, J. V., Shero, M., Griffiss, J. M., Cole, J. A., Parsons, N. J., Smith, H., Morse, S. \& A PICELLA, M. A. (1990). In vitro and in vivo modifications of Neisseria gonorrhoeae lipopolysaccharide epitope structure by sialylation. Journal of Experimental Medicine 171, 1649-1664.

Markwell, M. A. K., HaAs, S. M., Bieber, L. L. \& Tolbert, N. E. (1978). A modification of the Lowry procedure to simplify protein determination in membrane and lipoprotein samples. Analytical Biochemistry 87, 206-210.

Nelson, S. L. \& Frank, G. H. (1989). Purification and characterization of a $94 \mathrm{kDa}$ Pasteurella haemolytica antigen. Veterinary Microbiology 21, 57-66.

OgunNariwo, J. A. \& SCHRyvers, A. B. (1990). Iron acquisition in Pasteurella haemolytica: expression and identification of a bovine-specific transferrin receptor. Infection and Immunity 58, 2091-2097.

Pettersson, A., Kuipers, B., Pelzer, M., Verhagen, E., Tiesjema, R. H., Tommassen, J. \& Poolman J. T. (1990). Monoclonal antibodies against the 70-kilodalton iron-regulated protein of Neisseria meningitidis are bactericidal and strain specific. Infection and Immunity 58, 3036-3041.

Purdy, C. W., Livingston, C. W., Frank, G. H., Cummins, J. H., COLE, N. A. \& LOAN, R. W. (1986). A live Pasteurella haemolytica vaccine efficacy trial. Journal of American Veterinary Medical Association 188, 589-591.

SCHIEMANN, D. A. \& ShOPE, S. R. (1991). Anaerobic growth of Salmonella typhimurium results in increased uptake by Henle 407 epithelial and mouse peritoneal cells in vitro and repression of a major outer membrane protein. Infection and Immunity 59, 437-440.

Shewen, P. E. \& WILKIE, B. N. (1983). Pasteurella haemolytica cytotoxin neutralizing activity in sera from Ontario beef cattle. Canadian Journal of Comparative Medicine 47, 497-498.

SHeweN, P. F. \& WILKIE, B. N. (1988). Vaccination of calves with leukotoxic culture supernatant from Pasteurella haemolytica. Canadian Journal of Veterinary Research 52, 3036.

SMITH, H. (1990). Pathogenicity and the microbe in vivo. Journal of General Microbiology 136, 377383.

Squire, P. G., Smiley, D. W. \& Croskell, R. B. (1984). Identification and extraction of Pasteurella haemolytica membrane proteins. Infection and Immunity 45, 667673.

Sutherland, A. D., Jones, G. F. \& Poxton, I. R. (1990). The susceptibility of in vivo-grown Pasteurella haemolytica to ovine defence mechanisms in vitro. FEMS Microbiology Immunology 64, 269278.

TSaI, C. M., Boykins, R. \& Frasch, C. E. (1983). Heterogeneity and variation among Neisseria meningitidis lipopolysaccharides. Journal of Bacteriology 155, 498-504.

TSAI, C. M. \& FrasCh, C. E. (1982). A sensitive silver stain for detecting lipopolysaccharides in polyacrylamide gels. Analytical Biochemistry 119, 115-119.

Ward, K. H., ANWar, H., Brown, M. R. W., Wale, J. \& Gowar, J. (1988). Antibody response to outer membrane antigens of Pseudomonas aeruginosa in human burn wound infection. Journal of Medical Microbiology 27, 179-190. 
Wilkie, B. N., MARKham, R. J. F. \& SheWEn, P. E. (1980). Response of calves to lung challenge exposure with Pasteurella haemolytica after parental or pulmonary immunization. American Journal of Veterinary Research 41, 1773-1778.
Yates, W. D. G., Stockdale, P. H. G., Babiuk, L. A. \& Smith, R. J. (1983). Prevention of experimental bovine pneumonic pasteurellosis with an extract of Pasteurella haemolytica. Canadian Journal of Comparative Medicine 47, 250-256. 